А.І.Яковенко,

доктор філософських наук,

доиент СНУ імені Володимира Даля

\title{
ОСОБЛИВОСТІ РЕЛІГІЙНОГО СВІТОГЛЯДУ ПЕРІОДУ КИЇВСЬКОЇ РУСІ
}

Процес демократизації і збільшення міжкультурних зв'язків у сучасному світі стосується декількох сфер суспільства, у тому числі й релігійної. Світогляд нації повинен спиратися на традиційні цінності України.

Особливості релігійного світогляду періоду Київської Русі багато дослідників аналізували досить грунтовно. Становлять інтерес розробки, в яких здійснено аналіз релігійного світогляду періоду Київської Русі як феномену духовної культури, а саме праці Є.Анічкова, архімандрита Кипріана (Керна), Я.Баровського, М.Буслаєва, Г.Вагнера, Н.Гальковского, Г.Глінки, В.Даля, Д.Зеленіна, Д.Ліхачева, О.Котляревського, О.Мілєра, В.Мількова. М.Нікольського, М.Попова, В.Проппа, Б.Рибакова, П.Строєва, М.Тареєва, Б. Успенського.

Цікавою, на наш погляд, є праця релігійного філософа М.Тареєва «Християнський світогляд». Автор розглядає світоглядні проблеми духовності з метою визначити шляхи подолання сучасної кризи християнства. Релігійний дослідник, зокрема зазначає, що свобода у святоотецькій спадщині є самою суттю духовного існування людини [10].

Монографія О.Котляревського «Про похоронні звичаї язичниківслов'ян» аналізує найрізноманітніші джерела, а саме: мову, народний побут слов'ян, листи, збережені літописом різних слов'янських народів, могильні пам'ятники [8].

Праця Є. Анічкова «Язичництво й давня Русь» містить аналіз староруських джерел, що оповідають про вірування, які середньовічні книжники вважали язичницькими: досліджуються повчання проти язичників. Автор характеризує народну культуру середньовічної Русі [1].

Архімандрит Кипріан (Керн) у праці «Антропологія святого Григорія Палами» описує зародження, зміни, розвиток і збереження основних християнських доктрин. Наприклад, коли ми відкриваємо доступ пристрастям, то розум розсіюється, блукає навколо 
плотського й земного, навколо різноманітних насолод і пристрасних помислів про них. Однак його потрібно сконцентрувати на високому розумі, на пізнанні абсолютної істини [7].

Мета статті - цілісний, концептуальний розгляд релігійного світогляду періоду Київської Русі як філософської проблеми та виявлення сутності цього явища. При цьому експлікація даного феномену постає в межах екзистенціальної діалектики міфологічної і релігійної свідомості як синтез двох взаємодоповняльних форм суспільної свідомості.

Досягнення поставленої мети передбачає вирішення таких завдань: обгрунтування звернення до особливостей традиційного духовного життя представників києво-руського язичництва; висвітлення християнства як носія принципово нової релігійної свідомості києво-руської духовної культури; з'ясування сутності проблеми релігійного світогляду києво-руської духовної культури в контексті діалектики міфологічної і релігійної свідомості.

Аналіз екзистенціальної діалектики християнства і архаїчних вірувань як опозиційних світоглядних систем свідчить про багатоваріантність результатів даної рефлексії. За умови усвідомлення цієї опозиційності києво-руська людина або визнавала християнські ідеї, відкидаючи язичницькі, або зовсім не приймала християнства. В разі відсутності розуміння несумісності тих або інших віроповчальних принципів християнства й архаїчних вірувань виникали явища синкретичної релігійності, але найчастіше елементи язичницької традиції набували певної екзистенції в релігійній свідомості суспільства, що християнізувалося, набуваючи в ньому автономного й самодостатнього положення.

Києво-руське язичництво - це культурне явище, що являє собою тип релігійного руху, який грунтується на релігійній свідомості, основою якого є віровчення язичництва (генотеїзм, політеїзм). Світоглядною основою язичництва є традиція шанування роду, природи, рідної віри зі своїм пантеоном богів. Особливістю язичницької віри є релігійний синкретизм культу, ритуалу, віри.

Повсякденний та традиційно-побутовий характер язичницького світогляду вказує на автономність відповідних святкових ритуалів, при цьому ритуально-магічні риси календарної обрядовості не мають будь-яких слідів політеїстичних поглядів. Відсутність жорсткої залежності й взаємозв'язку між власне політеїстичною 
вірою й комплексом магічних вірувань $є$ фактом. Показний фрагмент києво-руської культури, що зберігся до наших днів, - це календарні свята, що містять у собі безліч архаїчних мотивів і пережиткових явищ.

Екзистенціальна основа релігійності язичників - традиційні язичницькі культи, обряди й магічні практики. Віра тлумачиться як «родова віра» $[5,347]$. Система моральних цінностей києво-руського язичництва визначається нерозривною єдністю людини і природи. Цілісність людини і природи виражає гармонію буття - творчих сил природи і суспільства. Боги язичницької Русі найповніше представлені в джерелах у зв'язку зі створенням Володимиром київського пантеону в 980 р., де на чолі язичницького сонму богів був бог-громовержець Перун. Ім'я бога Перуна очолює список богів пантеону князя Володимира в «Повісті врем'яних літ». Язичництво виникає як конструкт інституціональної сукупності древньорелігійних, суспільно-родових груп, об’єднань [4, 311-352].

Язичники одухотворяли всі явища навколишньої природи. Вони думали, що ними керує воля богів, подібна до їх власної, i тому намагалися спрямувати цю волю на свою користь чи, принаймні, пізнати іiі. За таких умов цілком природно, що києво-руське язичництво не витримало зіткнення 3 християнством, 3 його певним $\mathrm{i}$ ясним віровченням, 3 його розвинутим культом, 3 цілим класом духовенства, яке енергійно впроваджувало його в життя суспільства. Для києво-руської інтелігенції не могло бути вибору між ним і примітивною релігією предків, і вона охоче приймала християнство. Християнство в народну масу проникло внаслідок проповіді, внаслідок добровільного прийняття, а не внаслідок тільки спонукання.

Ми вважаємо, що найбільшою силою опору відрізняється та релігія, яка постає у формі ясного і певного світогляду, при цьому має розвинутий культ і підтримується впливовим і привілейованим класом. Нічого подібного не можна сказати про києво-руське язичництво. Вірування їх були невизначені, неясні й відзначалися відсутністю узагальнювального філософського начала.

Утвердження християнства як нового релігійного світогляду почалося на Русі зі справжнього двовірства, а не тільки 3 перенесення в християнство частини колишніх язичницьких вірувань. Йдеться про поєднання язичництва 3 християнством як цілої віри. Частина язичницької догматики була перенесена з язичництва до 
християнства. Початковий етап християнізації Київської Русі складався з формування своєрідного політеїстичного світогляду, в якому шанування християнського Бога та святих приєднувалося до культу старих язичницьких божеств.

Звернення до проблематики масової києво-руської релігійності вимагає врахування специфіки буденної релігійної свідомості через експлікацію міфологічної й релігійної свідомості як стану відображення дійсності києво-руською людиною. Емпіричні спостереження свідчать, що буденна релігійна свідомість характеризується традиційністю засобів передачі від покоління до покоління, стабільністю і стереотипністю форм існування, а саме: своєрідною субординацією нормативного, емоційного й концептуального компонентів, при якій ведучим $є$ регулятивно-емоційний комплекс; особливу роль тут відіграють обряди, ефективно закріплюючи релігійні вірування в кожному новому поколінні [14, 149-172].

Міфологічна й релігійна свідомість мають як спільне, так і принципово відмінне. Міфологічна свідомість дає людині можливість переживати світ, як щось цілісне і неподільне. Простір і час, як невід'ємні ознаки фізичної реальності, не мають тут суттєво відмінних характеристик. Період існування і місце будь-якого природного об'єкта визначаються наявністю і кількістю тієї магічної сили, за допомогою якої даний предмет впливає на всі інші речі в світі. Сама людина включена в ту саму систему взаємозв'язків. Він не є домінуючим або чільним елементом, найбільш розумним або наближеним до богів порівняно з іншими мешканцями землі. Він, подібно до всіх інших живих істот і неживих об'єктів, перебуває в системі безконечності й підпорядкований загальним правилам i законам. Тому протилежність природного світу надприродному в міфології дана лише в потенції, в можливості, а особливістю міфології «є ототожнення, як повне, так і часткове, природне і надприродне, перетворення одного в інше» $[12,138]$.

Міфологічній свідомості властива слабка диференціація суб'єкт-об'єктних відносин, ототожнення з будь-яким об'єктом природи, з будь-яким віртуальним об'єктом, що є продуктом уяви. Для релігійної свідомості подібне ототожнення можливе лише за умови навмисного зречення розуму з його ясністю і логікою.

Релігійна свідомість спирається на містичний досвід, при цьому відбувається імітація архаїчних афективних станів, імітація тотож- 
ності, які для міфологічної свідомості є початковими. Міфологічна свідомість базується на афективних станах, великих емоціях. Релігійна свідомість починається $з$ розважливих тверджень. В релігійній свідомості інтелігібельна складова досягається за допомогою певних дій і $є$ результатом певних установок свідомості й відповідної спрямованості мислення. Воно є метою для закріплення та затвердження сакрального досвіду, тимчасом як у міфологічній свідомості первісний стан тотожності з космосом є причиною, що породжує нуминозне почуття [6, 116-117].

Первісні міфи виявляються трансформованими в найвищі ступені релігійної свідомості. Сприйняття елементів старого змісту новими формами релігії $є$ найважливішою закономірністю іiі розвитку, сутність якої полягає в тому, що наступні стадії релігійної свідомості базуються на тих основних уявленнях, які, раз виникнувши, потім видозмінюються відповідно до суспільних умов, при цьому змінюються, частково зберігаючись у своєму первісному вигляді. Таким чином, на кожній новій стадії розвитку релігія приймає пройдені нею стадії, що виступають як основа більш пізніх модифікацій, включаючи в себе на кожній стадії, поряд із сучасним, елементи свого минулого й майбутнього. При цьому суть релігійної свідомості полягає, безсумнівно, не в тому, що становить своєрідність iii різних форм, а в тому, що властиве всім іiі формам і модифікаціям.

Ставши самостійною формою суспільної свідомості, релігія залишається міфологічним світоглядом. Успадкування релігією первісної міфології має спільні для них риси: фантастичне відображення світу, віра у створені фантазією образи як реальні і примарне переборення суперечностей людського буття, освячення й санкціонування існуючого суспільного й космічного порядку. Як і в архаїчній міфологічній свідомості, в релігії міф тісно пов'язаний з культом [3, 120-128]. С. Токарев вирішальне значення у зрощенні релігії 3 первісною міфологією вбачає у такій їх спільній рисі, як загальна фантазія, що сприяє вже на ранніх стадіях розвитку включенню міфологічних уявлень у сферу релігії. «Зрощуючись із релігійно-магічними обрядами, міфологія становить суттєву частину змісту релігійних вірувань. На пізній стадії розвитку - у світових релігіях міфи стають обов'язковими для всіх віруючих, релігійними догмами» $[11,375]$.

Релігійний світогляд розуміється як комплекс уявлень про світ і про місце в ньому людини, про ставлення людини до дійсності, що 
оточує iii, і до самої себе. Такий підхід дає можливість визнати, що релігійний світогляд є ядром суспільної і особистісної свідомості. Основу релігійного відношення в системі релігійного вірування становлять релігійні ідеї. Визнання цих ідей достеменними є якісною характеристикою релігійної свідомості, в межах якої формується особистісний релігійний світогляд.

Релігійна особистісна свідомість зазвичай розглядається як вищий рівень духовної активності особи, як ідеальна (психічна) форма діяльності, орієнтована на віддзеркалення й перетворення дійсності. При цьому найважливішою функцією особистісної свідомості є уявна побудова дій і передбачення їх наслідків, контроль і управління поведінкою особи.

Релігійну свідомість окремої людини треба сприймати як комунікативну систему, з масивами інформації, з яких формується особистісний релігійний світогляд, що постає як сума сегментів впорядкованих уявлень про природний і надприродний світи. Це розширює можливості аналізу релігійних явищ, оскільки відокремлює саму релігійно значущу інформацію від механізмів іiі зберігання до обробки іiі і трансляції. Особистісна релігійна свідомість характеризується наявністю таких специфічних компонентів, як релігійне мислення, релігійні відчуття і релігійна віра, при цьому їх наявність зумовлює існування таких елементів релігії, як ритуальна поведінка і діяльність релігійних організацій.

Християнство, як світова релігія, усвідомило себе носієм принципово нової етики нового розуміння людини, нових законів людського буття, нової релігійної свідомості. Насамперед, надзвичайно високо оцінюється гідність людської особистості, тому що надзвичайно високою є гідність досконалої Особистості - Ісуса Христа, яка стає моральним ідеалом для тих, хто сприймає Новий Завіт в усій його повноті. Християнське етичне знання грунтується на тому, що людина, як найвище із творінь, була створена за образом і подобою Бога - абсолютно найкращої, найдосконалішої, духовної й вільної Особистості й творчої Першопричини всякого творіння. Сліди цієї високої богоподібності назавжди залишились у людській природі. Крім того, якщо раніше основним моральним вектором було виконання певних етичних норм, які мають визначений кінцевий характер, то для новозавітної людини нормою життя стає прагнення до безконечного духовного вдосконалення, зміст і суть 
якого не рабська реалізація, а безконечне прагнення до Нього як до Отця Небесного [9, 685-713]. Тому моральні настанови в Новому Завіті мають характер не стільки незаперечних законницьких імперативів, скільки душевних взірців внутрішнього етичного устрою, який протиставляється тому повсякденному ладу, при якому, за словами Ісуса Христа, «з серця виходять лихі думки...» (Мф. 15:19).

Ісус Христос проголошує систему цінностей, яку виражено в понятті «Царства Божого». В цьому Його Одкровення, Його «добра вість» і Його «Новий Завіт». Царство Боже, або Царство Небесне, те, в що вірять і на що мають надію. Біблійні притчі зображують «Царствіє» як найвищу цінність, заради якої варто віддати все інше.

Нова система цінностей, Новий Завіт, протиставляється старій системі цінностей, Старому Завіту. Вся Нагорна проповідь збудована на цій протилежності. Праведності книжників і фарисеїв протиставляється інша, більш висока моральність, без якої неможливо увійти до Царства Небесного (Мф. 5:20). Стара система в цьому протиставленні найчастіше охоплюється поняттям закону (Тора). «Усі бо Пророки й Закон до Іоанна - провіщували» (Лк. 16:16; Мф. 11:12-13). Те, що протиставляється закону, не є імператив, або залякування, а є, навпаки, полегшення, звільнення, радість та блаженство. Царство Небесне є блаженство, як про це сповіщається в заповідях про те, хто є блаженним (Мф. 5:3-11; Лк. 6:20-23), воно є радість, котра дарується людині, найвища краса і благодать.

Протиставлення закону й благодаті, закону й любові, закону й Царства Божого проходить через усі Свангелія і чітко формулюється як основний принцип християнства в пролозі євангеліста Іоанна: «закон бо через Мойсея був даний, а благодать та правда 3'явилися через Ісуса Христа» (Ів. 1:17) [2].

Звідси, згідно з поглядами С.Франка, постає індивідуальна своєрідність моральних якостей людини. Внутрішній устрій особистості, стан людського духа невидимі нікому, крім самої особистості та Бога. Тому неможливий будь-який людський суд над особистістю, бо він безпредметний і некомпетентний через неможливість правильно судити про те, що тут підлягає оцінюванню завдяки незрівнянності й потаємності особистості. Особистість є дещо більш глибоке й цінне, ніж будь-яка мораль. Цінність людської особистості - не в ступені іiі підпорядкування моральним вимогам, а в силі й гостроті іiі потягу до вищого абсолютного блага. 
Ступінь близькості людини до Бога, інтенсивність іiі потягу, іiї тяга до Бога, за словами С.Франка, одна визначає істинну придатність й доброякісність людини [13, 287-314].

Отже, визнання релігійного світогляду періоду Київської Русі багатоелементним комплексом 3 різною мірою системної інтеграції його окремих частин створює можливість розгляду взаємодії архаїчних вірувань і християнства як синкретизму двох опозиційних світоглядних систем. У разі відсутності розуміння, несумісності тих або інших віроповчальних принципів християнства й язичництва виникали явища синкретичної релігійності, але найчастіше елементи язичницької традиції інтегрувалися в релігійну свідомість християнського суспільства із пріоритетом християнського світорозуміння в системі релігійного світогляду періоду Київської Русі.

\section{ЛІТЕРАТУРА}

1. Аничков Е.В. Язычество и древняя Русь. - М., 2003. - 440 с.

2. Библия: Книги Священного Писания Ветхого и Нового Завета (канонические) - СПб., 1991. - 1193 с.

3. Борунков Ю.Ф. Структура религиозного сознания. - М., 1975. - 364 с.

4. Гантаев Н.М. Церковь и феодализм на Руси. - М., 1960. -513 с.

5. Греков Б.Д. Культура Киевской Руси. Общественный строй и духовная культура. -М. ; Л., 1951. - 547 с.

6. Звиревич B.T. Мифологический тип античних концепций человека // Историко-философские исследования. - 1978. - №5. - С. 115-119.

7. Киприан (Керн) архимандрит. Антропология святителя Григория Паламы. - М., 1996. - 448 с.

8. Котляревский А.А. О погребальных обычаях язычников славян. - СПб., 1868. $-290 \mathrm{c}$.

9. Николин И.П. Философия христианства // Богословский вестник. 1903. - Июнь-июль. - С. 613-758.

10.Тареев М.М. Христианское мировоззрение. Основы христианства : Соч. в 3-х тт. - Сергиев Посад, 1908 . - Т.3. - 719 с.

11.Токарев С.А. Ранние формы религии и их развитие. - М., 1964. - 526 с.

12. Угринович Д.М. Сущность первобытной мифологии и тенденции ее эволюции // Вопросы философии. - 1980. - №9. - С. 115-183.

13. Франк С.Л. Философия и жизнь. - СПб., 1912. - 569 с.

14. Unbgaun B.O. La religion des ancien Slaves // Introduction a Thistoire de religions. - T.3. - Paris, 1948. -638 p. 
Яковенко А.І. Особливості релігійного світогляду періоду Київської Русі.

У статті обгрунтовується думка про те, що проблема релігійного світогляду періоду Київської Русі, характеризуючи стан релігійної свідомості в контексті екзистенціальної діалектики міфологічної і релігійної свідомості, постає як цілісний системний комплекс питань, аналіз релігійного розуміння і вплив якого на українське суспільство є актуальним.

Зміст статті - експлікація сукупності істотних і відмінних якостей системи релігійного світогляду періоду Київської Русі в цілому з перспективою подальших досліджень і розробки методично обгрунтованих підходів зі зміцнення духовності українського суспільства.

Ключові слова: релігійний світогляд, християнство, свідомість, релігія, Ісус Христос, віра, особистість.

Яковенко А.И. Особенности религиозного мировоззрения периода Киевской Руси.

В статье обосновывается мысль о том, что проблема религиозного мировоззрения периода Киевской Руси, характеризующая состояние религиозного сознания в контексте экзистенциональной диалектики мифологического и религиозного сознания, выступает как целостный системный комплекс вопросов, анализ религиозного понимания и влияние которого на украинское общество является актуальным.

Содержание статьи - экспликация совокупности существенных и отличительных качеств системы религиозного мировоззрения периода Киевской Руси в целом, с перспективой дальнейших исследований и разработки методически обоснованных подходов по укреплению духовности украинского общества.

Ключевые слова: религиозное мировоззрение, христианство, сознание, религия, Иисус Христос, вера, личность.

Yakovenko B.I. The Peculiarities of the Religious Worldview of Kyiv Rus Period.

The article explains the idea that the problem of religious worldview of Kyiv Rus Period which characterizes the state of religious consciousness in the context of existential dialectics of the mythological and religious consciousness is revealed as anentire complex of questions, the religious analysis and influence of which on the Ukrainian society are urgent. Therefore the research of that reflection is the aim of the article.

The content of the article is the explication of total essential and distinctive properties of the religious worldview of Kyiv Rusperiod in general with the perspective of further research and development methodologically based approaches to strengthen spirituality of the Ukrainian society.

Key words: religious worldview, Christianity, consciousness, religion, Jesus Christ, faith, personality. 